\section{ANTIMETABOLITES PRODUCED \\ BY MICROORGANISMS. IV ${ }^{1)}$}

\author{
L-THREO- $\alpha$-AMINO- $\beta, \gamma-$ \\ DIHYDROXYBUTYRIC ACID
}

\section{Sir :}

An unidentified streptomycete* when grown aerobically at $28^{\circ} \mathrm{C}$ in a medium containing (in g/liter) glucose, 10 ; Bactopeptone (Difco) 5 ; yeast extract (Difco) 3 ; and ferrous ammonium sulfate hexahydrate, 0.03 : produced a substance $(90 \mathrm{mg} /$ liter at 70 hours) inhibitory to the growth of $E s^{-}$ cherichia coli on Davis and Mingroli minimal $\operatorname{agar}^{2}$. The growth inhibition was relieved by addition of L-serine or L-threonine to the minimal medium.

The antimetabolite was isolated from the filtered broth by adsorption on Dowex 50 resin $(50 \sim 100 \mathrm{mesh})$ in the hydrogen ion form. The activity was eluted with $5 \%$ aqueous pyridine. After removal of the pyridine, the antimetabolite was absorbed on Florisil packed in ethanol and eluted with ethanol-water $(3: 1)$. Further purification was achieved by gradient elution from a second Florisil column with ethanolwater $(9: 1 \sim 1: 1)$. The active fractions were desalted by adsorption on Dowex 50 resin (50 100 mesh) in the hydrogen ion form followed by elution with $5 \%$ aqueous pyridine solution. The active material crystallized from ethanol-water as colorless needles, m.p. $210^{\circ} \mathrm{C}$ (dec.), $[\alpha]_{\mathrm{D}}^{25}-13.3^{\circ}\left(c 1, \mathrm{H}_{2} \mathrm{O}\right.$; literature $\left.^{3)}-13.7^{\circ}\right),-1.1^{\circ}(c 1,2.2 \mathrm{~N} \mathrm{HCl}$; literature ${ }^{4)}-1.8^{\circ}$ ). Anal. calcd. for $\mathrm{C}_{4} \mathrm{H}_{9} \mathrm{NO}_{4}$ : C 35.55, H 6.71, N 10.37. Found: C 35.91, $\mathrm{H} 6.80, \mathrm{~N} 10.65$. The compound behaved as a neutral amino acid on electrophoresis. Assuming the compound to be an $\alpha$-amino acid (later confirmed by mass spectrometry), $\mathrm{C}_{2} \mathrm{H}_{5} \mathrm{O}_{2}$ remained to be assigned. This fragment can only correspond to $-\mathrm{CH}(\mathrm{OH})$ $\mathrm{CH}_{2} \mathrm{OH}$, making the antimetabolite $\alpha$ amino- $\beta, \gamma$-dihydroxybutyric acid. Nuclear magnetic resonance in $\mathrm{D}_{2} \mathrm{O}$ was in agreement with this structure, showing four non- exchanged protons with three centered at $\delta 4.25$ and one at $\delta 4.7$. Four stereoisomers are possible for this amino acid and all have been synthesized ${ }^{3)}$ in connection with the determination of the absolute configuration of sphingosine. The optical rotations of the antimetabolite in water and dilute acid clearly indicate the L-threo configuration (I). This assignment is in agreement with the observation of Bodanszky and PerLman ${ }^{5}$ that diasymmetric amino acids from microbial sources have either the $\mathrm{L}$-threo or $\mathrm{D}$ erythro configuration.

Concentration of the crude fermentation solution prior to Florisil chromatography gave crystals of L-4-hydroxyproline, m.p. $250^{\circ} \mathrm{C}$ (dec.), $[\alpha]_{\mathrm{D}}^{25}-76.9^{\circ}$ (c $1, \mathrm{H}_{2} \mathrm{O}$; literature $\left.{ }^{6)}-76.3^{\circ}\right)$. Anal. calcd. for $\mathrm{C}_{5} \mathrm{H}_{9} \mathrm{NO}_{3}$ : C $45.79, \mathrm{H} 6.92, \mathrm{~N}$ 10.68. Found: C 46.10, $\mathrm{H} 6.91, \mathrm{~N} 10.53$. This compound gave the atypical yellow color with ninhydrin. In order to determine the relative amounts of dihydroxyaminobutyric acid (I) and hydroxyproline in the crude fermentation product, each was silylated using bis(trimethylsilyl) trifluoroacetamide in acetonitrile and compared by gas chromatography with a silylated sample of crude material. The trimethylsilyl (TMS) derivatives were separable on UCW98 and $\mathrm{OV}-17$ columns at $160^{\circ} \mathrm{C}$ with triTMS-hydroxyproline (M.W. 347) preceeding the tetra-TMS-derivative of I (M.W. 423) in order of elution from both columns. A third smaller peak was identified by gas chromatography-mass spectrometry (GC-MS) as tri-TMS-glutamic acid (M.W. 363).<smiles>NC(C(=O)O)C(O)CO</smiles>

The amounts of the three amino acids present in the crude fermentation solids (after adsorption and desorption from Dowex 50) were calculated to be: I, $8.9 \%$; L-4hydroxyproline, $11.2 \%$ and L-glutamic acid, $2.8 \%$. The two latter compounds may have

* Streptomyces sp. \#1-1 (HLR $330 \mathrm{~A}$ ), isolated 1965 from field soil of Piscataway, N. J., a gift of Prof. H. Lechevalier, Institute of Microbiology, Rutgers University, the State University of New Jersey, N. J., U.S.A. 
arisen from the hydrolysis of peptides in Bacto-peptone.

The mass spectrum of the tetra-TMS derivative of I was in agreement with the assigned structure with small peaks at $\mathrm{m} / \mathrm{e}$ 408 and 320 due to the loss of $-\mathrm{CH}_{3}$ and $-\mathrm{CH}_{2} \mathrm{OSi}\left(\mathrm{CH}_{3}\right)_{3}$ from the molecular ion, a medium size peak at $\mathrm{m} / \mathrm{e} 306$ due to loss of $-\mathrm{COOSi}\left(\mathrm{CH}_{3}\right)_{3}$ and a base peak at $\mathrm{m} / \mathrm{e}$ 218. This ion is diagnostic for N-TMS$\alpha$-amino acid TMS-esters ${ }^{7)}$ and corresponds to the fragment ion

\section{$\left(\mathrm{CH}_{3}\right)_{3} \mathrm{SiNH}=\mathrm{CH}-\mathrm{COOSi}-\left(\mathrm{CH}_{3}\right)_{3}$.}

The highest $\mathrm{m} / \mathrm{e}$ peak observed for the tri-TMS derivatives of hydroxyproline and glutamic acid were respectively 332 and 348 , each due to the loss of a methyl radical from the molecular ion.

We thank Dr. C. G. Scotr of the Physical Chemistry Department for the GC-MS determination and the Fermentation Pilot Plant under Mr. B. TAKENKIN for their participation in this project.
J. W. Westley
D. L. Pruess
L. A. Volpe
T. C. Demny
A. Stempel

Chemical Research Department Hoffmann-La Roche Inc. Nutley, New Jersey 07110, U.S.A.

\section{References}

1) Scannell, J. P.; D. L. Pruess, M. Kellett, T. C. Demny \& A. Stempel: Antimetabolites produced by microorganisms. III. 2-Aminopurine-6-thiol (thio-guanine). J. Antibiotics $24: 328 \sim 329, \quad 1971$

2) Davis, B. D. \& C.S. Mingoli: Mutants of Escherichia coli requiring methionine or vitamin $B_{12}$. J. Bact. $60: 17 \sim 28,1950$

3) Hamel, E. E. \& E. P. Painter: The stereochemistry of the four $\alpha$-amino- $\beta, \gamma$-dihydroxybutyric acids. J. Am. Chem. Soc. 75 : 1362 1368, 1953. Our assignments are relative to $\mathrm{L}$-serine rather than $\mathrm{D}$-glyceraldhyde as used in this reference.

4) Greenstein, J. P. \& M. Winitz: Chemistry of the amino acids. John Wiley and Sons, New York 1961, page 90 . The $[\alpha]_{\mathrm{D}}^{25}$ value in acid was calculated from the molar rotation listed in this reference.

5) Bodanszky, M. \& D. Perlman: Origin of D-amino acids in microbial peptides: Rule of $\alpha$-epimerization. Nature 218:291 292, 1968

6) Merck Index, 8 th edition, 1968, pp. 554 555

7) Bergaström, K.; J. Gứtler \& R. Blomstrand: Trimethylsilylation of amino acids. Analytical Biochem. $34: 34 \sim 87,1970$ 